\section{Substrate Type and Temperature on Germination Parameters of Butterfly Pea}

\author{
Sean M. Campbell ${ }^{1}$, Brian J. Pearson ${ }^{1}$, \\ and S. Christopher Marble ${ }^{1}$
}

AdDitional INDEX words. Clitoria ternatea, germinability, medicinal, rockwool, specialty crop

Summary. Butterfly pea (Clitoria ternatea) is a unique perennial and leguminous plant that produces brightly colored flowers that can be used as a $\mathrm{pH}$-dependent natural food colorant in culinary and cosmetic preparations. Butterfly pea is commonly propagated from seed. Because of the increased interest in its commercial applications, effective production techniques are necessary to ensure consistent and successful commercial production. The objective of this research was to determine the influence of the substrate type and temperature on butterfly pea germination. Two substrate types (rockwool and commercial soilless substrate mix) and three temperatures $\left(70,80\right.$, and $\left.90^{\circ} \mathrm{F}\right)$ were evaluated to determine their effects on germination of butterfly pea seed. Collected and calculated germination data included germination capacity (G), mean germination time (MT), coefficient of variation of the germination time $\left(\mathrm{CV}_{\mathrm{t}}\right)$, mean germination rate $(\mathrm{MR})$, uncertainty of the germination process $(U)$, and synchrony of the germination process $(Z)$. Differences were observed among substrate temperatures for the $M T, c v_{t}$, and $M R$ values, with germination greater at both 70 and $80^{\circ} \mathrm{F}$ than at $90{ }^{\circ} \mathrm{F}$. Similarly, significant differences among substrate types were observed for the $G, M T, \mathrm{CV}_{t}$, and MR values, with germination of seeds in rockwool outperforming seeds in soilless substrate mix. Because of the high priority for successful and uniform germination in commercial plant production operations, the results suggest that commercial germination of butterfly pea would be best in rockwool at $70{ }^{\circ} \mathrm{F}$. Results of this study can be used for the commercial production of butterfly pea, for which propagation from seed is the primary means of plant production.

$\mathrm{O}$ riginated in the Asian tropics, butterfly pea (Clitoria ternatea) is an herbaceous, perennial, leguminous twiner that has become naturalized in the East and West Indies, South and Central Americas, India, and China (Barik et al., 2007; Morris, 2009; Park and Knox, 2016). Flowers are deep blue to purple; when dried, butterfly pea flower extract can be used as a traditional food colorant with a longer shelf life

Received for publication 24 Jan. 2020. Accepted for publication 23 Mar. 2020.

Published online 24 April 2020.

${ }^{1}$ Mid-Florida Research and Education Center, University of Florida, Institute of Food and Agricultural Sciences, Department of Environmental Horticulture, 2725 South Binion Road, Apopka, FL 32703

The authors declare that the research was conducted in the absence of any commercial or financial relationships that could be construed as a potential conflict of interest.

S.M.C. is a Graduate Research Assistant.

B.J.P. and S.C.M. are Assistant Professors.

B.J.P. is the corresponding author. E-mail: bpearson@ ufl.edu.

This is an open access article distributed under the CC BY-NC-ND license (https://creativecommons.org/ licenses/by-nc-nd/4.0/).

https://doi.org/10.21273/HORTTECH04583-20 and greater ease of use than synthetic blue colorants (Siti Azima et al., 2017). Recent health concerns associated with the consumption of synthetic food colorants (Chu et al., 2016; McCann et al., 2007) will likely further popularize the use of butterfly pea in food and beverage preparation, especially in the United States, where recent increased interest in this plant and its applications have already been documented (Simonson, 2016).

Soilless substrate is commonly a mix of organic and inorganic components blended for a particular use or application, and commercial plant production often relies on germination blends or mixtures containing high proportions of peat or coir to facilitate high water retention characteristics. An alternative substrate, rockwool is primarily composed of basaltic rock heated to $\approx 1600{ }^{\circ} \mathrm{F}$ and then spun to create a fibrous mass. Use of rockwool in commercial plant production operations has increased in recent years through the expansion of countries importing rockwool, an increase in the number of crops grown in rockwool, and through the development of a wider range of products containing rockwool (Bussell and McKennie, 2004). This has multiple advantages over soil-based substrates, primarily in the sterility, consistency, and water- and nutrient-holding capacities of the substrate. High temperatures required to manufacture rockwool render it biologically inert and, therefore, free from potential weeds, pests, and diseases that might normally hinder germination. This manufacturing process also renders a very consistent substrate that possesses an ideal air-to-water ratio for horticultural production, especially for seed germination (Allaire et al., 2005).

Butterfly pea is a heavy seeder, with between 6 and 3400 total seeds per plant produced from an assay of 19 varying accessions of butterfly pea. This high seeding rate has led to germination from seed as the primary method of propagation for butterfly pea (Fig. 1) (Morris, 2009). High levels of plantavailable water are important for butterfly pea seedlings, with the literature recommending field seeding following a rainfall event $(650-1250 \mathrm{~mm})$ and when the possibility for subsequent rain is likely (Collins and Grundy, 2005). More accurately, Das et al. (2017) determined that the inherent moisture content of butterfly pea seeds is $6.8 \%$; although that can be altered to between $5 \%$ and $12 \%$ with no negative effects, germinability was maximized at $10 \%$ seed moisture content. This is often accomplished through scarification or compromise of the seedcoat. Nagar and Meena (2015) found that

\begin{tabular}{llll}
\hline $\begin{array}{l}\text { Units } \\
\text { To convert U.S. to SI, } \\
\text { multiply by }\end{array}$ & U.S. unit & SI unit & $\begin{array}{l}\text { To convert SI to U.S., } \\
\text { multiply by }\end{array}$ \\
\hline 29.5735 & $\mathrm{fl} \mathrm{oz}$ & $\mathrm{mL}$ & 0.0338 \\
0.3048 & $\mathrm{ft}$ & $\mathrm{m}$ & 3.2808 \\
2.54 & inch $(\mathrm{es})$ & $\mathrm{cm}$ & 0.3937 \\
25.4 & inch $(\mathrm{es})$ & $\mathrm{mm}$ & 0.0394 \\
16.3871 & inch & $\mathrm{cm}^{3}$ & 0.0610 \\
$\left({ }^{\circ} \mathrm{F}-32\right) \div 1.8$ & ${ }^{\circ} \mathrm{F}$ & ${ }^{\circ} \mathrm{C}$ & $\left({ }^{\circ} \mathrm{C} \times 1.8\right)+32$
\end{tabular}




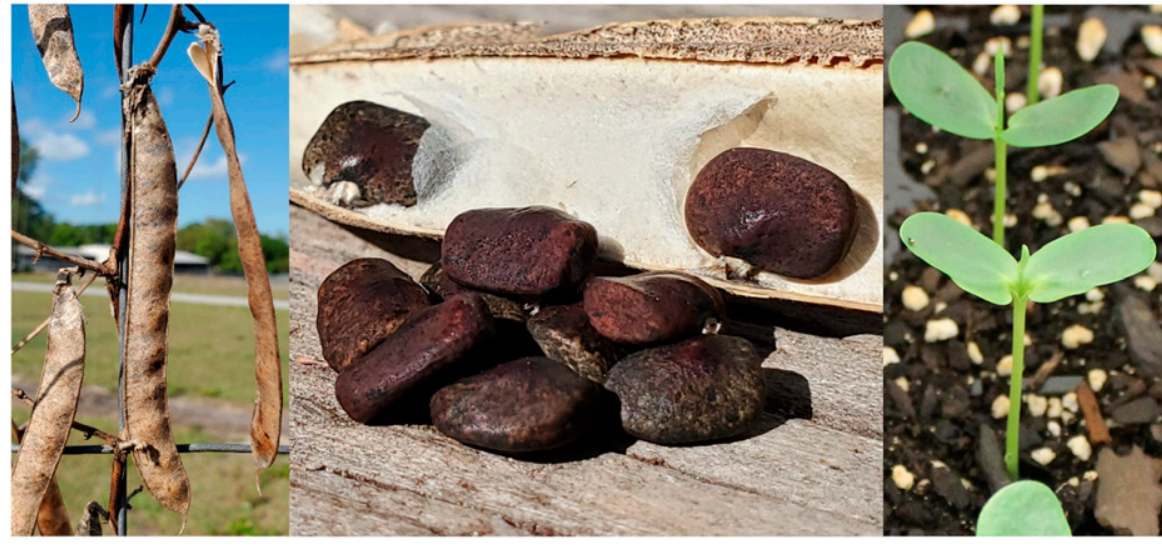

Fig. 1. Dried butterfly pea seed pods remaining on the vine from the previous year's growth (left). Butterfly pea seeds after being removed from the dried seed pods described (middle). Seven-day-old butterfly pea seedlings in soilless substrate under a vented humidity dome (right).

either physical (abrasion with sandpaper) or chemical (soaking in sulfuric acid) scarification methods can increase germination by $70.5 \% \mathrm{com}$ pared to that of a control (Makasana et al., 2016).

Research examining the influence of temperature on germination success has been evaluated for butterfly pea; however, conflicting observations of the optimal germination temperature $\left(\mathrm{T}_{\mathrm{o}}\right)$ appear in the literature. Selvamaleeswaran et al. (2011) found that exposing butterfly pea seed to temperatures of $16,28,30$, and $35{ }^{\circ} \mathrm{C}$ resulted in germinability rates of $56 \%, 60 \%, 65 \%$, and $20 \%$, indicating a peak $\mathrm{T}_{\mathrm{o}}$ of $30{ }^{\circ} \mathrm{C}$ and a drastic reduction in germination at $35{ }^{\circ} \mathrm{C}$. This reduction was likely caused by thermo-inhibition, or the inability of seeds to germinate at high temperatures. Similarly, McDonald (2002) evaluated butterfly pea seed germination at temperatures between 8 and $44^{\circ} \mathrm{C}$, with peak germination between 24 and $28{ }^{\circ} \mathrm{C}$ and a rapid decrease in germinability above or below that range. Thermoinhibition was again observed at the highest imposed temperature treatments $\left(\geq 40{ }^{\circ} \mathrm{C}\right)$. The mean germination rate followed a similar trend, increasing proportionally with an increased substrate temperature from 8 to $28{ }^{\circ} \mathrm{C}$, maximizing at $\mathrm{T}_{\mathrm{O}}$ of $32{ }^{\circ} \mathrm{C}$, and then declining between 36 to $40{ }^{\circ} \mathrm{C}$. Differences in observations reported by Selvamaleeswaran et al. (2011) and McDonald (2002) were likely caused by their use of cotton and paper, respectively, as germination media.
Because of the conflicting responses to imposed temperature treatments and a lack of research examining seed germination in commonly used commercial media, research examining the influence of substrate composition and temperature on germination of butterfly pea is needed for commercial plant production. To address this need, six germination metrics were measured and recorded for seed of butterfly pea in two varying common commercial germination media subjected to one of three temperature treatments. Results from this work will provide plant producers and growers with critical information necessary to successfully germinate butterfly pea.

\section{Materials and methods}

SEeD. Three different trials were performed using the same experimental design: one each per week across the span of 3 weeks beginning on 17 Sept. and ending on 8 Oct. 2018. For each trial, 216 butterfly pea seeds were harvested from a single plant grown in a $100-\times 48$-ft gutter-connected greenhouse with $30 \%$ lightreducing polycarbonate paneling located in Apopka, FL (lat. $28.64^{\circ} \mathrm{N}$, long. $\left.81.55^{\circ} \mathrm{W}\right)$. On 17 Sept., 24 Sept., and 1 Oct., day 0 for each experimental trial, seeds for each trial were scarified mechanically using a razor blade according to the procedure described by Mackay et al. (2001) before being soaked in deionized water (DI) water for $24 \mathrm{~h}$.

Substrate type. Two different substrate types were used for the experiment: soilless substrate mix
(30\% pine bark, $48 \%$ peat, $10 \%$ perlite, and $12 \%$ vermiculite; Fafard $4 \mathrm{P}$; Sun Gro Horticulture, Agawam, MA) and rockwool (Grodan, Roermond, The Netherlands). On 18 Sept., 25 Sept., and 2 Oct., day 1 for each experimental trial, three 36count soilless substrate plug trays were made by cutting 72 -count plug trays $(1.5$ inches long $\times 1.5$ inches wide $\times 2.25$ inches high) in half. The trays were then filled with soilless substrate, and each plug was seeded with a single scarified and soaked butterfly pea seed $\approx 0.25$ inch under the soils surface. Three 36 -count rockwool cube sheets were also prepared by cutting 98-count rockwool cube sheets $\left(1.5\right.$ inch $\left.^{3}\right)$, soaking them for $30 \mathrm{~min}$ in water adjusted to $\mathrm{pH} \mathbf{5 . 5}$ using a $\mathrm{pH}$ down buffering solution (General Hydroponics, Sebastopol, $\mathrm{CA}$ ), and then seeding with the scarified and soaked butterfly pea seeds. The six substrate sheets were placed in a propagation unit located within a laboratory environment.

Substrate temperature. The propagation unit used in this experiment consisted of a multitier shelfed structure (Compact SunLite 3-Tier Garden; Gardener's Supply Co., Burlington, VT), with each of the three shelves equipped with a 7.5-inch vented humidity dome (HydroFarm, Petaluma, CA), a 10- $\times 20.75$-inch heat mat (Vivosun, Shanghai, China), fluorescent lighting (T5; Sunblaster, Langley, BC, Canada), and a mini thermohygrometer (Mondi, Vancouver, BC, Canada) to measure environmental conditions within each dome. A digital thermohygrometer (AcuRite, Lake Geneva, WI) was placed on the exterior of the propagation unit to record ambient environmental conditions, with mean temperatures and humidity of $73{ }^{\circ} \mathrm{F}(56 \%)$ and $73{ }^{\circ} \mathrm{F}(55.5 \%)$, respectively, for trials 2 and 3 (data for trial 1 were unavailable). Heating mats were programmed to maintain substrate temperatures of 70,80 , and 90 ${ }^{\circ} \mathrm{F}$ for the three experimental substrate temperature treatments imposed in the study. Top and side vents of the humidity domes were fully closed to maintain a constant humidity level. Lights were positioned $\approx 2$ inches from the top of the dome, providing illumination between 55 and $90 \mu \mathrm{mol} \cdot \mathrm{m}^{-2} \cdot \mathrm{s}^{-1}$ at the outer corners and the center of the substrate sheet, respectively, 
throughout the duration of the experiment. Each of the six substrate sheets had $\approx 25 \mathrm{~mL}$ of water applied daily using a laboratory wash bottle (Thermo Fisher Scientific, Waltham, MA).

Germination parameters. Six germination parameters were collected, calculated, and reported throughout the experiment according to the procedures outlined by Ranal et al. (2009). These included the following: germination capacity (G); mean germination time (MT); coefficient of variation of the germination time $\left(\mathrm{CV}_{\mathrm{t}}\right)$; mean germination rate $(\mathrm{MR})$; uncertainty of the germination process $(\mathrm{U})$; and synchrony of the germination process $(\mathrm{Z}) . \mathrm{G}$, also referred to as germinability, is characterized as the binary response of whether a fully formed cotyledon is visible above the substrate surface at the end of the observations (germinated/nongerminated). That qualitative value was then converted to a quantitative attribute, percentage, for the entire treatment group for statistical analyses and reporting. MT is the mean of the germination time per day weighted by the number of seeds germinated per data measurement time interval (days). The mean germination time provided a quantifiable assessment of the average amount of time necessary for maximum germination of an experimental group. Use of the weighted mean for this measurement accounts for variance in the number of seeds germinated per time interval. The $\mathrm{CV}_{t}$ was a measurement of the variability in relation to the MT, allowing for additional comparisons independent of the mean germination time magnitude.

Calculated as the reciprocal of MT, the MR quantified germination rate increases and decreases in relation to $1 / \mathrm{MT}$ rather than $\mathrm{MT}$ alone. $\mathrm{U}$ was a measurement of the degree of uncertainty associated with the frequency and distribution of germination within an experimental group. Because germination of only one seed can change $U$, this measurement value quantified the degree of spread of germination as influenced by temporal factors. Conversely, $\mathrm{Z}$ represents the degree of overlap that existed during germination and is only produced when two or more seeds finished germination within the same time interval (Ranal et al., 2009).

Experimental Design. The experiment was organized as a $2 \times 3$ factorial in a completely randomized design, with substrate type and substrate temperature assigned as independent variables. Three replicates were cultivated for each treatment combination, one per experimental trial. Substrate temperature, vented humidity dome interior temperature and humidity (percent), and ambient laboratory temperature and humidity (percent) were recorded daily for the portions of trial 1 (20-23 Sept.), trial 2 (26 Sept.-1 Oct.), and trial 3 (3-8 Oct.) when germination was occurring (Table 1). Germination parameters were analyzed based on a collected response and then reported as percentages; a restricted maximum likelihood mixed model analysis was performed using the data collected from the 36 germinated seeds per experimental trial (JMP $^{\circledR}$ Pro 14; SAS Institute, Cary, NC) with post hoc mean separation tests performed using Tukey's honest significant difference test and a germination trial with variance within treatment combination replicates defined as the random error term. Statistical tests were considered significant if $P \leq 0.05$.

\section{Results}

Temperature AND HUMidity. With some notable exceptions, the substrate temperature, vented humidity dome interior temperature and humidity, and ambient laboratory temperature and humidity were all consistent within expectations because measurements correlated positively with the increasing experimental temperature treatments. Although the mean interior temperature was higher for the $80^{\circ} \mathrm{F}$ treatment than the $70{ }^{\circ} \mathrm{F}$ treatment for trial 3 , this measurement is considered secondary to the substrate temperature, which is a more accurate representation of the experimental treatment being applied. These inconsistencies were likely caused by fluctuations in the activity of the heating mats, which are attached to a controller that uses a thermometer placed in the substrate to regulate activation and duration to maintain the desired substrate temperature.

Germination PARAMETERS. No significant interactions existed between substrate temperature and type for any of the six germination parameters; therefore, the main effects of substrate temperature and substrate type were analyzed separately as independent factors (Table 2). Differences in germination capacity $(G)$ were observed for substrate type $(P=0.03)$, with rockwool $(91.7 \%)$ resulting in greater germination compared with the soilless substrate $(83.6 \%)$. G values of $70{ }^{\circ} \mathrm{F}(92.6 \%)$, $80{ }^{\circ} \mathrm{F}(88.4 \%)$, and $90{ }^{\circ} \mathrm{F}(81.9 \%)$ for the substrate temperature treatment groups indicated no significant difference, but the germination capacity was increased with increasing substrate temperatures (Table 2, Fig. 2).

Similar trends were observed for the $\mathrm{MT}, \mathrm{CV}_{\mathrm{t}}$, and $\mathrm{MR}$ parameters, with differences noted among substrate temperature and substrate type treatments. The MT of the substrate temperature treatments decreased as the temperature was increased from $70{ }^{\circ} \mathrm{F}(2.2 \mathrm{~d})$ to $80^{\circ} \mathrm{F}(1.9 \mathrm{~d})$ to $90^{\circ} \mathrm{F}$ $(1.7 \mathrm{~d})(P=0.01)$, whereas rockwool $(2.1 \mathrm{~d})$ had a slower germination rate than the soilless substrate $(1.8 \mathrm{~d})$ treatment $(P=0.01)$. Therefore, a trend between higher MT values and increased $G$ values was noted and further reinforced by the MT values for the substrate temperature $\times$ substrate type interaction effect; the 70 ${ }^{\circ} \mathrm{F}$ rockwool $(2.3 \mathrm{~d}), 80{ }^{\circ} \mathrm{F}$ rockwool (2 d), and $70{ }^{\circ} \mathrm{F}$ soilless substrate (2 d) experimental treatments had the highest $\mathrm{G}$ values at $98 \%, 92 \%$, and $87 \%$, respectively.

Increased variations were observed within $\mathrm{CV}_{\mathrm{t}}$ values as the substrate temperature was increased for the 70 ${ }^{\circ} \mathrm{F}(20.4 \%), 80{ }^{\circ} \mathrm{F}(27.4 \%)$, and $90{ }^{\circ} \mathrm{F}$ $(37.7 \%)$ treatments $(P<0.01)$, whereas the substrate type affected the $\mathrm{CV}_{\mathrm{t}}$ values of the rockwool $(23.6 \%)$ and soilless substrate $(33.4 \%)$ treatments $(P=0.01)$. This would indicate that lower levels of variation result in higher $G$ values, which again was supported by the $\mathrm{CV}_{\mathrm{t}}$ values for the substrate temperature by substrate type interaction effect; the $80{ }^{\circ} \mathrm{F}$ rockwool $(19.4 \%)$ and $70{ }^{\circ} \mathrm{F}$ rockwool $(19.8 \%)$ treatments were the most uniform, followed by the $70{ }^{\circ} \mathrm{F}$ soilless substrate treatment (21.1\%).

Finally, as the substrate temperature increased, so did the MR values for the $70{ }^{\circ} \mathrm{F}\left(0.47 \mathrm{~d}^{-1}\right), 80{ }^{\circ} \mathrm{F}(0.53$ $\left.\mathrm{d}^{-1}\right)$, and $90{ }^{\circ} \mathrm{F}\left(0.60 \mathrm{~d}^{-1}\right)$ treatments $(P=0.03)$. Substrate type was similarly affected in the rockwool $\left(0.49 \mathrm{~d}^{-1}\right)$ 
Table 1. Recorded substrate temperature, vented humidity dome interior temperature, and humidity for trials 1,2 , and 3 of the 70,80 , and $90^{\circ} \mathrm{F}$ substrate temperature treatments for butterfly pea seeds.

\begin{tabular}{|c|c|c|c|c|c|c|c|c|c|}
\hline \multirow[b]{2}{*}{ Treatment temp. $\left({ }^{\circ} \mathbf{F}\right)^{\mathrm{z}}$} & \multicolumn{3}{|c|}{ Recorded substrate temp. $\left({ }^{\circ} \mathbf{F}\right)$} & \multicolumn{3}{|c|}{ Interior temp. $\left({ }^{\circ} \mathrm{F}\right)$} & \multicolumn{3}{|c|}{ Interior humidity (\%) } \\
\hline & Trial l & Trial 2 & Trial 3 & Trial l & Trial 2 & Trial 3 & Trial l & Trial 2 & Trial 3 \\
\hline 70 & $75.7^{y}$ & 77.4 & 77.5 & 75.2 & 76.6 & 76.5 & 66.7 & 68.8 & 65.5 \\
\hline 80 & 80.6 & 80.8 & 80.6 & 75.7 & 76.6 & 75.6 & 67.7 & 71.0 & 69.2 \\
\hline 90 & 82.8 & 82.8 & 83.7 & 79.2 & 78.6 & 77 & 70.5 & 69.8 & 71.2 \\
\hline
\end{tabular}

${ }^{\mathrm{z}}\left({ }^{\circ} \mathrm{F}-32\right) \div 1.8={ }^{\circ} \mathrm{C}$.

${ }^{\mathrm{y}}$ Mean of the environmental parameters collected daily for trial 1 (20-23 Sept.), trial 2 (26 Sept.-1 Oct.), and trial 3 (3-8 Oct.).

Table 2. Germination parameters for substrate temperature $\left(70,80\right.$, and $\left.90{ }^{\circ} \mathrm{F}\right)$ independent variables, substrate [rockwool (RW) and soilless substrate (SS)] independent variables, and temperature $\times$ substrate interaction effects for butterfly pea seeds.

\begin{tabular}{|c|c|c|c|c|c|c|c|c|c|c|c|c|}
\hline \multirow{2}{*}{$\frac{\text { Temp. }\left({ }^{\circ} \mathbf{F}\right) \times \text { substrate }^{\mathrm{z}}}{70 \times \mathrm{RW}}$} & \multicolumn{2}{|c|}{$\begin{array}{c}\mathrm{G}(\%)^{\mathrm{y}} \\
P=0.77^{*}\end{array}$} & \multicolumn{2}{|c|}{$\begin{array}{l}\text { MT (d) } \\
P=0.93\end{array}$} & \multicolumn{2}{|c|}{$\begin{array}{c}\mathrm{CV}_{\mathrm{t}}(\%) \\
P=0.15\end{array}$} & \multicolumn{2}{|c|}{$\begin{array}{c}\operatorname{MR}\left(\mathrm{d}^{-1}\right) \\
P=0.65\end{array}$} & \multicolumn{2}{|c|}{$\begin{array}{c}\mathrm{U} \\
P=0.36\end{array}$} & \multicolumn{2}{|c|}{$\begin{array}{c}\mathrm{Z} \\
P=0.17\end{array}$} \\
\hline & 98.15 & a & 2.29 & $\mathrm{a}$ & 19.82 & $\mathrm{a}$ & 0.44 & $\mathrm{a}$ & 0.79 & $\mathrm{a}$ & 0.64 & a \\
\hline $80 \times \mathrm{RW}$ & 91.67 & $\mathrm{a}$ & 2.04 & $\mathrm{a}$ & 19.42 & a & 0.49 & $\mathrm{a}$ & 0.74 & a & 0.73 & a \\
\hline $80 \times S S$ & 85.19 & a & 1.74 & $\mathrm{a}$ & 35.37 & a & 0.58 & $\mathrm{a}$ & 1.25 & a & 0.46 & $\mathrm{a}$ \\
\hline $90 \times \mathrm{RW}$ & 85.19 & a & 1.86 & $\mathrm{a}$ & 31.66 & a & 0.54 & a & 1.12 & a & 0.56 & $\mathrm{a}$ \\
\hline \multirow{3}{*}{$\operatorname{Temp}\left({ }^{\circ} \mathbf{F}\right)$} & 92.59 & a & 2.16 & $\mathrm{a}$ & 20.44 & $\mathrm{~b}$ & 0.47 & $\mathrm{~b}$ & 0.82 & $\mathrm{a}$ & 0.66 & a \\
\hline & 88.43 & a & 1.89 & $a b$ & 27.40 & $\mathrm{~b}$ & 0.54 & $a b$ & 0.99 & $\mathrm{a}$ & 0.60 & $\mathrm{a}$ \\
\hline & 81.94 & $\mathrm{a}$ & 1.70 & $\mathrm{~b}$ & 37.70 & $\mathrm{a}$ & 0.60 & $\mathrm{a}$ & 1.19 & $\mathrm{a}$ & 0.51 & $\mathrm{a}$ \\
\hline \multirow[t]{2}{*}{ Substrate } & \multicolumn{2}{|c|}{$P=0.03^{*}$} & \multicolumn{2}{|c|}{$P=0.01$ * } & \multicolumn{2}{|c|}{$P=0.01 *$} & \multicolumn{2}{|c|}{$P=0.02$ * } & \multicolumn{2}{|c|}{$P=0.11$} & \multicolumn{2}{|c|}{$P=0.12$} \\
\hline & 91.67 & $\mathrm{a}$ & 2.07 & $\mathrm{a}$ & 23.63 & $\mathrm{~b}$ & 0.49 & $\mathrm{~b}$ & 0.88 & $\mathrm{a}$ & 0.64 & a \\
\hline
\end{tabular}

$\mathrm{z}\left({ }^{\circ} \mathrm{F}-32\right) \div 1.8={ }^{\circ} \mathrm{C}$.

${ }^{y_{G}}=$ mean germination capacity, $\mathrm{MT}=$ mean germination time, $\mathrm{Cv}_{\mathrm{t}}=$ coefficient of variation of the germination time, $\mathrm{MR}=\mathrm{mean}$ germination rate, $\mathrm{U}=\mathrm{uncertainty}$ of the germination process, $\mathrm{Z}=$ synchrony of the germination process.

${ }^{*}$ Significance at $P \leq 0.05$; means ( $\mathrm{n}=36$ per experimental trial) within column with the same letter are not significantly different via Tukey's honest significant difference test $(P \leq 0.05)$.
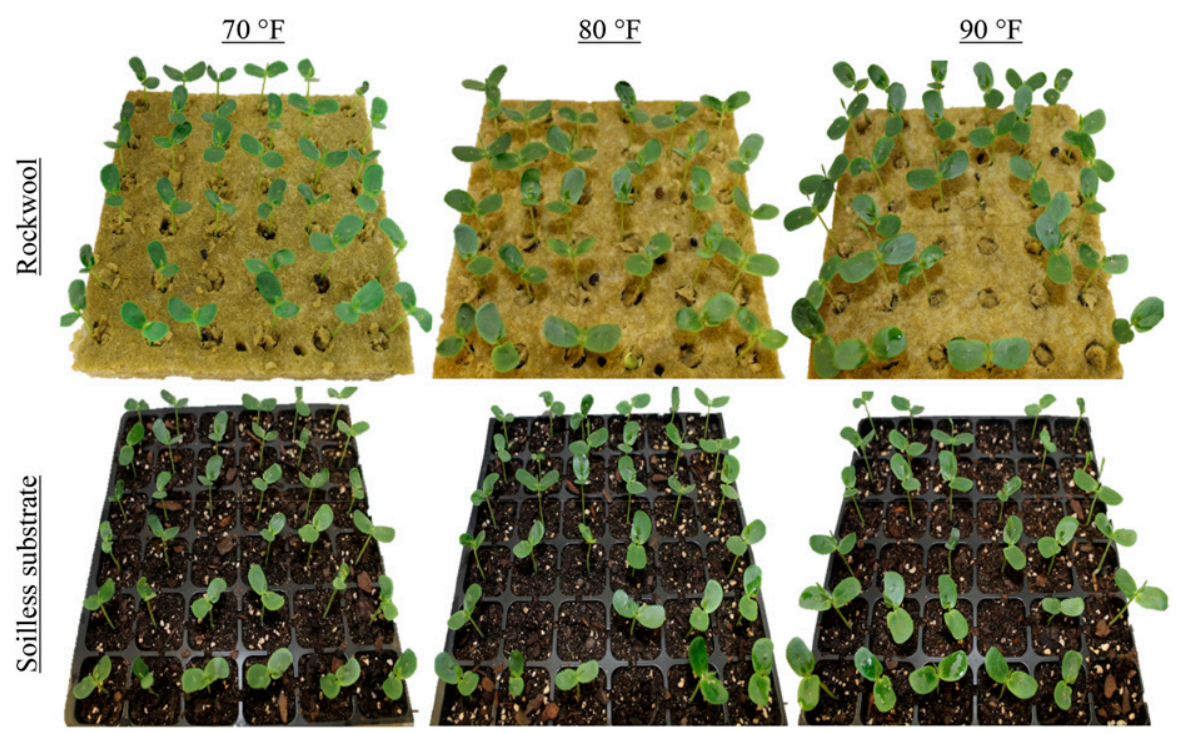

Fig. 2. Germinated butterfly pea seedlings in 36-count trays, three each for the rockwool and soilless substrate treatments, for the 70,80 , and $90{ }^{\circ} \mathrm{F}(21.1,26.7$, and $32.2^{\circ} \mathrm{C}$ ) substrate temperature treatments on the final day ( $23 \mathrm{Sept}$.) of experimental trial 1 . and soilless substrate $\left(0.58 \mathrm{~d}^{-1}\right)$ treatments $(P=0.03)$. Following the same trend as $\mathrm{MT}$, a longer germination time and subsequent lower germination rate exhibited the highest $\mathrm{G}$ values; the 70 ${ }^{\circ} \mathrm{F}$ rockwool $\left(0.44 \mathrm{~d}^{-1}\right)$ treatment combination had the lowest germination rate, followed by $70{ }^{\circ} \mathrm{F}$ soilless substrate $\left(0.49 \mathrm{~d}^{-1}\right)$ and $80{ }^{\circ} \mathrm{F}$ rockwool $\left(0.49 \mathrm{~d}^{-1}\right)$.

Although the uncertainty of the germination process (U) and the synchrony of the germination process $(\mathrm{G})$ responded similarly to treatments, observed trends offer insights into factors influential to the germination of butterfly pea. Lower $\mathrm{U}$ values indicated that germination was more concentrated in time; the rockwool and soilless substrate treatments had $U$ values of 0.88 and 1.12, respectively, whereas higher $\mathrm{Z}$ values exhibited by rockwool (0.64) as compared with those exhibited by the soilless substrate (0.54) treatment identified a higher degree of germination overlap. Similar trends were observed for 


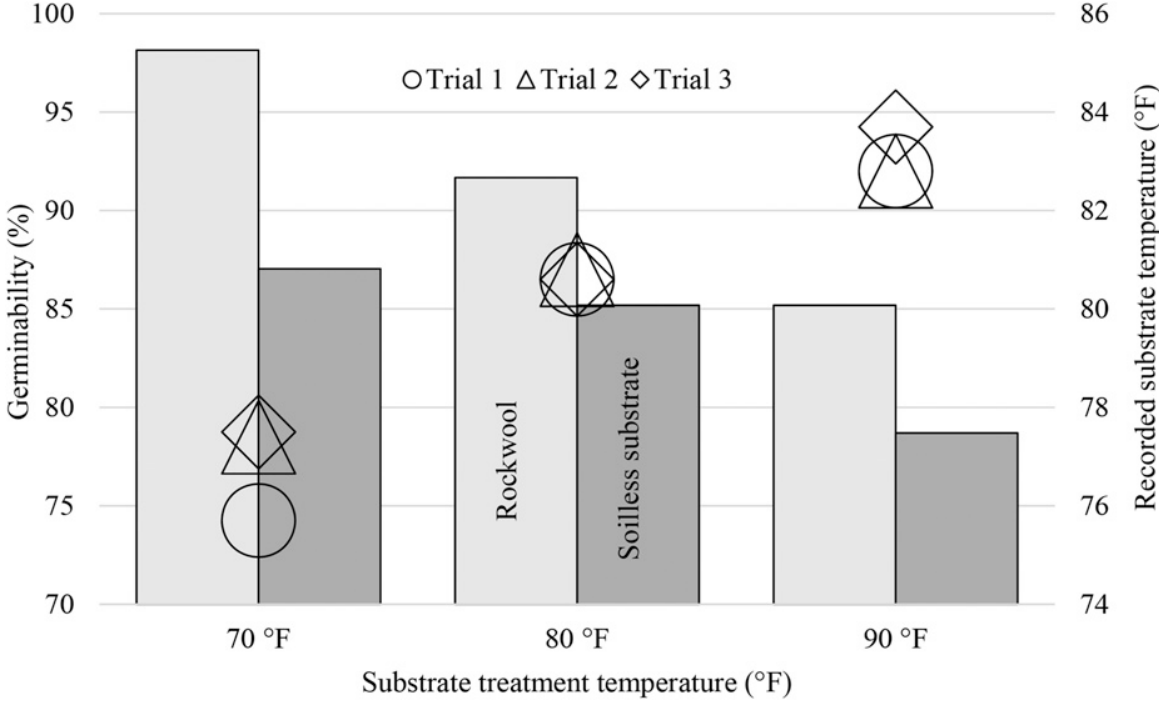

Fig. 3. Germinability (primary axis, clustered columns) of butterfly pea seeds in relation to the recorded substrate temperature (secondary axis, markers) for experimental trials 1,2 , and 3 of the rockwool and soilless substrate treatments and the 70,80 , and $90{ }^{\circ} \mathrm{F}$ substrate temperature treatments. $\left({ }^{\circ} \mathrm{F}-32\right) \div 1.8={ }^{\circ} \mathrm{C}$.

substrate temperatures with $U$ values of $0.82,0.99$, and 1.19 and $\mathrm{Z}$ values of $0.66,0.60$, and 0.51 , for the 70,80 , and $90{ }^{\circ} \mathrm{F}$ treatments, respectively.

\section{Discussion}

In the context of seed germination parameters, $T_{\mathrm{o}}$ is defined as the temperature at which maximal $G$ is observed. This is often achieved in the shortest MT and with the highest MR. Reductions in seed $G$ are observed when substrate temperatures fall below [suboptimal $\left.\left(<\mathrm{T}_{\mathrm{o}}\right)\right]$ or exceed [supraoptimal $\left.\left(>\mathrm{T}_{\mathrm{o}}\right)\right]$ the $\mathrm{T}_{\mathrm{o}}$ at a rate proportional to the absolute value of the difference. This occurs until either the lowest [base substrate temperature $\left(T_{b}\right)$ ] or the highest [ceiling substrate temperature $\left(\mathrm{T}_{\mathrm{c}}\right)$ ] temperatures at which germination can proceed are reached, resulting in thermo-inhibition. Although these phenological events and their underlying physiology are well-documented, there is some contest over the definition of $\mathrm{T}_{\mathrm{o}}$, primarily regarding whether it is a distinct temperature or a range of temperatures (Watt and Bloomberg, 2012).

Four of the six germination parameters $\left(\mathrm{G}, \mathrm{MT}, \mathrm{Cv}_{\mathrm{t}}\right.$, and $\mathrm{MR}$ ) were optimized when seeds were germinated in rockwool, with more consistent germinability when compared with those germinated in soilless substrate. Our results indicate that rockwool is a superior germination media compared to the soilless substrate mix for butterfly pea seeds, likely due to superior porosity and water-holding capacity of the rockwool, more consistency due to its manufacturing process, a lack of competitive organisms, or a combination of the three factors (Allaire et al., 2005). This also supports the conclusions of Collins and Grundy (2005) that butterfly pea requires high levels of available water during germination and seedling stages.

Similar trends were observed among treatments for the substrate temperature independent variable, with differences among three of the six germination parameters $\left(\mathrm{MT}, \mathrm{CV}_{\mathrm{t}}\right.$, and MR). Considering the relationship theorized between $\mathrm{G}$ values and increasing substrate temperatures, it can be concluded that butterfly pea produces a higher percentage of viable germinated seeds in a more consistent amount of time and at a more consistent rate when substrate temperature is decreased from 90 to 80 to $70{ }^{\circ} \mathrm{F}$ (Fig. 3).

This is consistent with $T_{o}$ values presented in the literature. $\mathrm{McD}$ Donald (2002) concluded that the $T_{o}$ was between 24 and $28{ }^{\circ} \mathrm{C}$, with $\mathrm{G}$ declining drastically at sub-optimal or supra-optimal temperatures. Although our observed $T_{o}$ is lower than values reported by McDonald (2002), the temperature at which thermo-inhibition occurred was similar. Differences in $T_{o}$ values between studies were likely due to the differences in substrates used; McDonald relied on moist seed-test filter paper in 9 -cm petri dishes to achieve germination. In their review, Olle et al. (2012) determined that when Grodan rockwool is saturated and then allowed to drain completely by gravitational pull, the remaining slab will contain $5 \%$ rockwool fibers, $15 \%$ pore space, and $80 \%$ water. The authors concluded that this ratio of water, or nutrient solution, to air promotes vigorous root growth.

\section{Conclusions}

Although faster germination and, therefore, lowered MT are often desired to reduce production time in commercial plant cultivation operations, this can lead to uneven or restricted emergence and a lack of cultivation consistency. Because uniformity is a high priority, the results suggest commercial germination of butterfly pea is maximized when the rockwool substrate is used at a substrate temperature of $\approx 70^{\circ} \mathrm{F}$. This is further confirmed by $\mathrm{G}$ values for the substrate temperature $\times$ substrate type interaction effects, where the $70{ }^{\circ} \mathrm{F}$ rockwool, $80{ }^{\circ} \mathrm{F}$ rockwool, and $70{ }^{\circ} \mathrm{F}$ soilless substrate treatment combinations exhibited the highest numbers of viable germinated seeds at $98 \%, 92 \%$, and $87 \%$, respectively. Although substrate temperature and type were both shown to significantly influence the germination success of butterfly pea, the influence of other commercial production parameters not evaluated in this study may be important.

\section{Literature cited}

Allaire, S.E., J. Caron, C. Ménard, and M. Dorais. 2005. Potential replacements for rockwool as growing substrate for greenhouse tomato. Can. J. Soil Sci. 85:67-74.

Barik, D.P., S.K. Naik, A. Mudgal, and P.K. Chand. 2007. Rapid plant regeneration through in vitro axillary shoot proliferation of butterfly pea (Clitoria ternatea L.) - A twinning legume. In Vitro Cell. Dev. Biol. Plant 43:144-148.

Bussell, W.T. and S. McKennie. 2004. Rockwool in horticulture, and its importance and sustainable use in New Zealand. N.Z. J. Crop Hort. 32:29-37.

Chu, B., J. Wilkin, M. House, M. Roleska, and M. Lemos. 2016. Effect of sucrose on thermal and $\mathrm{pH}$ stability of Clitoria ternatea extract. Intl. J. Food Processing Technol. 1(3):11-17. 
Collins, R. and T. Grundy (eds.). 2005. The butterfly pea book: A guide to establishing and managing butterfly pea pastures in central Queensland. Dept. Primary Industries and Fisheries, Brisbane, Qld, Australia.

Das, M.L., M. Sharma, and P. Sivan. 2017. Seed germination and seedling vigor index in Bixa orellana and Clitoria ternatea. Intl. J. Pure App. Biosci. 5:1519.

Mackay, W., T.D. Davis, and D. Sankhla. 2001. Influence of scarification and temperature on seed germination of Lupinus arboreus. Seed Sci. Technol. 29:543-548.

Makasana, J., J. Patel, V. Pillai, A. Sharma, B. Dholakiya, N. Gajbhiye, and R. Saravanan. 2016. Effect of seed treatment on germination and flavonoids diversity in accessions of butterfly pea (Clitoria ternatea). Indian J. Agr. Sci. 86:1553-1558.

McCann, D., A. Barrett, A. Cooper, D. Crumpler, L. Dalen, K. Grimshaw, E. Kitchin, K. Lok, L. Porteous, E. Prince, E. Sonuga-Barke, J.O. Warner, and J. Stevenson. 2007. Food additives and hyperactive behaviour in 3 -year-old and 8/9-year-old children in the community: A randomised, double-blinded, placebocontrolled trial. Lancet 370:1560-1567.

McDonald, C. 2002. Germination response to temperature in tropical and subtropical pasture legumes. 1. Constant temperature. Anim. Prod. Sci. 42:407419.

Morris, J.B. 2009. Characterization of butterfly pea (Clitoria ternatea L.) accessions for morphology, phenology, reproduction and potential nutraceutical, pharmaceutical trait utilization. Genet. Resources Crop Evol. 56:421-427.

Nagar, R.P. and S. Meena. 2015. Effect of physical and chemical scarification and ageing on hardseededness in Clitoria ternatea. Range Mgt. Agrofor. 36:79-83.

Olle, M., M. Ngouajio, and A. Siomos. 2012. Vegetable quality and productivity as influenced by growing medium: A review. Zemdirbyste 99:399-408.

Park, B.S. and G.W. Knox. 2016. Flowering vines for Florida. 18 Feb. 2020. $<$ https://edis.ifas.ufl.edu/pdffiles/MG/ MG09700.pdf>.
Ranal, M.A., D.G.d. Santana, W.R. Ferreira, and C. Mendes-Rodrigues. 2009. Calculating germination measurements and organizing spreadsheets. Braz. J. Bot. 32:849-855.

Selvamaleeswaran, P., J. Wesely, B. Vennila, and S. Balakrishnan. 2011. Dormancy breaking and seed germination techniques for Clitoria ternatea. Linn. Biotechnol. Appl. Biochem. 1:185-192.

Simonson, R. 2016. A mood-ring ingredient makes cocktails change color. 18 Feb. 2020.<https://www.nytimes.com/ 2016/07/06/dining/blue-cocktailsblure-butterfly-pea-flower.html>.

Siti Azima, A.M., A. Noriham, and N. Manshoor. 2017. Phenolics, antioxidants and color properties of aqueous pigmented plant extracts: Ardisia colorata var. elliptica, Clitoria ternatea, Garcinia mangostana and Syzygium cumini. J. Funct. Foods 38:232-241.

Watt, M.S. and M. Bloomberg. 2012. Key features of the seed germination response to high temperatures. New Phytol. 196:332-336. 